\title{
Characterization of Inclusion Complex of Croton zehntneri Essential Oil and $\beta$-Cyclodextrin Prepared by Spray Drying and Freeze Drying
}

\author{
Fonseca, L.;* Rocha, M. S; Brito, L. C. F; Sousa, E. S.; Reinaldo, F. S.; \\ Pereira, F. M. M.; Santos, F. E. P; de Lima, S. G.
}

Rev. Virtual Quim., 2019, 11 (2), 529-542. Data de publicação na Web: 8 de abril de 2019

http://rvq.sbq.org.br

\section{Caracterização do Complexo de Inclusão do Óleo Essencial de Croton zehntneri e $\beta$-Ciclodextrina Preparados Através da Secagem por Atomização e Liofilização}

\begin{abstract}
Resumo: Croton zehntneri (CZ) é uma espécie aromática da família Euphorbiaceae, nativa do Nordeste do Brasil, rica em óleo essencial (CZEO) com propriedades antioxidante, vasorelaxante, bactericida e fungicida. Apesar dos inúmeros potenciais biológicos e farmacológicos, óleos essenciais são instáveis e possuem limitada solubilidade em água, características que podem ser melhoradas pela formação de complexos de inclusão com ciclodextrinas (CDs). No presente estudo, o complexo de inclusão de CZEO e $\beta$-CD foi preparado por co-precipitação acoplada à liofilização e secagem por atomização. $O$ complexo de inclusão foi caracterizado por espectroscopia vibracional (espectroscopia Raman e FT-IR) e a eficiência de complexação determinada por cromatografia gasosa acoplada à espectrometria de massa (CG-EM). Foi observado que a co-precipitação acoplada à liofilização possibilitou uma maior eficiência de complexação quando comparada ao spray drying. A espectroscopia Raman confirma a formação do complexo de inclusão entre CZEO e $\beta$-CD por ambos os métodos de preparação.
\end{abstract}

Palavras-chave: Complexo de Inclusão; spray drying; liofilização; Raman; ATR-FTIR.

\begin{abstract}
Croton zehntneri (CZ) is an aromatic species of the Euphorbiaceae family, native to Northeast of Brazil, rich in essential oil (CZEO) with antioxidant, vasorelaxant, bactericidal and fungicidal properties. Despite the numerous biological and pharmacological potentials, essential oils are unstable and have limited solubility in water, characteristics that can be improved by the formation of inclusion complexes with cyclodextrins (CDs). In the present study, the inclusion complex of CZEO and $\beta-C D$ was prepared by co-precipitation coupled to freeze drying and spray drying. The inclusion complex was characterized by vibrational spectroscopy (Raman spectroscopy and FT-IR) and the complexation efficiency determined by gas chromatography coupled to mass spectrometry (GC-MS). It was observed that coprecipitation coupled to lyophilization allowed greater complexation efficiencies when compared to the spray drying. Raman spectroscopy confirms the formation of the inclusion complex of $\beta-C D$ and CZEO by both preparation methods.
\end{abstract}

Keywords: Inclusion Complex; spray drying; freeze drying; Raman; ATR-FTIR.

\footnotetext{
* Federal University of Piaui, Postgraduate Program in Chemistry, Chemistry Department, Natural Sciences Center, CEP 64049-550, Teresina-PI, Brazil.

$M$ fonseca.lorenna@gmail.com DOI: $\underline{10.21577 / 1984-6835.20190040}$
} 


\section{Characterization of Inclusion Complex of Croton zehntneri Essential Oil and $\beta$-Cyclodextrin Prepared by Spray Drying and Freeze Drying}

Lorenna Fonseca, ${ }^{\mathrm{a}}$ Marcio dos S. Rocha, ${ }^{\mathrm{b}}$ Larisse C. F. Brito, ${ }^{\mathrm{b}}$ Edymilaís S. Sousa, ${ }^{a}$ Fernanda S. Reinaldo, ${ }^{b}$ Francisca M. M. Pereira, ${ }^{b}$ Francisco Eroni. P. Santos, ${ }^{c}$ Sidney G. de Lima ${ }^{a}$

${ }^{a}$ Federal University of Piauí, Postgraduate Program in Chemistry, Chemistry Department, Natural Sciences Center, CEP 64049-550, Teresina-PI, Brazil.

${ }^{b}$ Federal University of Piauí, Chemistry Department, Natural Sciences Center, CEP 64049-550, Teresina-PI, Brazil.

${ }^{c}$ Federal University of Piauí, Postgraduate Program in Materials Science and Engineering, CEP 64049-550, Teresina-PI, Brazil.

* fonseca.lorenna@gmail.com

Recebido em 6 de março de 2019. Aceito para publicação em 6 de março de 2019

1. Introduction

2. Experimental

2.1. Plant material

2.2. Essential oil extraction

2.3. GC-MS conditions

2.4. Inclusion complexes preparation

2.5. Inclusion complexes characterization

\section{Results and Discussion}

3.1. CZEO chemical composition

3.2. Inclusion complexes preparation

3.3. Inclusion complexes characterization

3.4. ATR-FTIR spectroscopy

3.5. Raman spectroscopy

\section{Conclusion}

\section{Introduction}

Essential oils (EOs) are natural, volatile and complex compounds, occasionally, characterized by a strong odour, extracted from various aromatic plants. They are very 
complex natural mixtures, which can contain a variety of components at different concentrations. Essential oils have become an integral part of everyday life and can be used as natural additives in many foods and in the compounding of cosmetics and perfumes, as well as in pharmaceutical industry because of their antibacterial, antifungal, antioxidant and anti-carcinogenic properties. ${ }^{1,2}$

Croton is the second largest genus of Euphorbiaceae, with approximately 1200 species distributed mainly in the tropical regions of the world. ${ }^{3,4}$ Several species of Croton present essential oils and active constituents such as terpenoids, flavonoids and alkaloids. ${ }^{5}$ Published results on the essential oil of species of the genus Croton verified that the essential oil of $C$. zehntneri and $C$. nepetaefolius species are constituted by monoterpenoids and sesquiterpenoids, as well as phenylpropanoids. C. argyrophylloides presents monoterpenoids and sesquiterpenoids, but does not contain phenylpropanoids. ${ }^{6,7}$

Among the species of this genus, Croton zehntneri Pax et Hoffm. (Euphorbiaceae) is an aromatic plant native of the Caatinga ecosystem from the Northeast Brazil, where it is popularly called canelinha, canela de cunhã or canela-brava. It is a sub-shrub and deciduous plant, and its aroma varies among specimens of this plant collected in different regions of the Northeast, due to the variation in the concentration of the most abundant chemical constituents in their essential oils. Thus, four chemical types are distinguished for this specie: anethole - for the specimens collected in Fortaleza-CE and Viçosa-CE; eugenol - for those collected in Areia BrancaRN and Quixadá-CE; methyl-eugenol - for those collected in Ipu-CE and Oeiras-PI; estragole - for the specimens collected in Tianguá-CE and Granja-CE. The leaves of $C$. zehntneri are used to prepare teas, which are employed by local people to treat nervous disorders, anxiety, seizures, insomnia and to relieve gastrointestinal disturbances. ${ }^{5-9}$

\section{Estragole (1-methoxy-4-(2-} propenyl)benzene, also known as methyl chavicol) is a phenylpropene and a natural constituent of several aromatic plants essential oils such as basil (Ocimum basilicum L., Lamiaceae), tarragon (Artemisia dracunculus L., Asteraceae), anise (Pimpinella anisum L., Apiaceae), and fennel (Foeniculum vulgare var vulgare, Apiaceae). ${ }^{10,11}$ Further studies has shown that estragole is used as flavouring agent in seasonings, non-alcoholic beverages and condiments due to insecticidal, antiviral, antimicrobial, acaricidal, myorelaxant, anticonvulsant properties. ${ }^{2,10,12-}$ 17

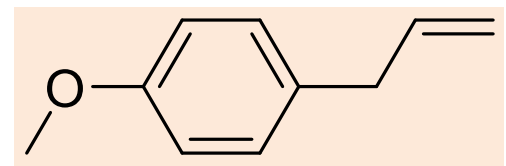

Figure 1. Chemical structure of estragole

Despite the variety of activities presented by the OEs, it has restricted applications as pharmaceutical products and food preservatives because the limited water solubility, unstable to light, heat, and oxygen, and poor bioavailability. Thus, the application fields of the representative essential oil in the food, medication, cosmetic industries and restricted characteristics can be improved by the formation of inclusion complex with cyclodextrins (CDs) without losing their bioactivity. ${ }^{18-20}$

CDs are non-toxic cyclic oligosaccharides consisting of 6 ( $\alpha$-cyclodextrin), 7 ( $\beta$ cyclodextrin), 8 ( $\gamma$-cyclodextrin) or more glucopyranose units linked by $\alpha-(1,4)$ bonds, derived from enzymatic degradation of starch or by metabolism of certain bacteria, such as Bacillus macerans. ${ }^{21} \mathrm{CDs}$ are ring molecules, but due to the lack of free rotation at the level of bonds between glucopyranose units, they 
are not cylindrical but, toroidal or coneshaped. CDs cavity diameter is determined by the number of glucose units in the $C D$ and control the size of the guest that can be encapsulated. They have a relatively hydrophilic external surface, which helps CDs to be dissolved in water and a hydrophobic interior cavity allowing them to include hydrophobic guests. The interaction between guest and $C D$ leads to the formation of noncovalent inclusion complexes, either in solution or solid state. Inclusion complex formation is a dynamic equilibrium allowing the guest to diffuse reversibly from the $C D$ cavity. ${ }^{22,23}$ The $\beta-C D$ has minimal solubility in water, thus is most likely to precipitate crystals, and it is most commonly used because of its high encapsulation efficiency, suitable cavity dimensions and low cost. ${ }^{24-26}$

The choice of preparation method has been reported to affect the physicochemical properties and physiologic performances of $C D$ based drug delivery systems. ${ }^{27}$ Several methods have been reported for the preparation of solid drug/CD complexes. Examples includes co-evaporation, coprecipitation, spray drying, freeze-drying, kneading, sealed-heating, milling/co-grinding, microwave irradiation and supercritical fluid technology..$^{23,28,29}$ Most of these processing methods require either a comparatively high energy input, employ organic solvents, or both. ${ }^{30}$

The inclusion complex can be used to combat the microbial resistance also, reducing the concentration of the compounds and the necessary doses used. In addition, the use of molecules with characteristics to form inclusion complex as CDs associated with antimicrobial substances can be improved the water solubility and extend the half-life. ${ }^{31,32}$

The purpose of this study was to prepare inclusion complex of $C$. zehntneri essential oil and $\beta$-cyclodextrin by co-precipitation coupled to freeze drying and spray drying, evaluating the efficiency of complexation of each method by GC-MS, ATR-FTIR and Raman spectroscopy.

\section{Experimental}

\subsection{Plant material}

Leaves of C. zehntneri Pax et Hoffm were collected in October 2016 in Simões-PI city, Brazil, for the extraction of volatile constituents. A voucher specimen was identified and deposited in the Graziela Veloso Herbarium of the Federal University of Piaui under number 29131. SISGEN A9CE308.

\subsection{Essential oil extraction}

C. zehntneri essential oil (CZEO) was obtained from the leaves $(100.0 \mathrm{~g})$ by hydrodistillation using a Clevenger-type distillation apparatus for approximately $3.0 \mathrm{~h}$. At the end of the process, the resulting oil was collected, dried with sodium sulphate, weighed and stored under refrigeration. The oil was solubilized in $n$-hexane for gas chromatography and mass spectrometry analysis.

\subsection{GC-MS conditions}

For the chemical composition characterization of CZEO, a gas chromatograph coupled to mass spectrometer (GC-MS) was used. A Shimadzu Chromatograph, model CGMS-QP2010 SE equipped with AOC-5000 automatic injector and SLB- $5 \mathrm{~ms}$ column $(30 \mathrm{~m} \times 0.25 \mathrm{~mm} \times 0.25$ $\mu \mathrm{m})$ was used. The conditions for the CG-MS analysis were as follows: Helium as carrier gas at a flow rate of $1.0 \mathrm{~mL} \cdot \mathrm{min}^{-1}$, a temperature of $250{ }^{\circ} \mathrm{C}$ in the injector; a temperature program, starting at $60{ }^{\circ} \mathrm{C}(3.0 \mathrm{~min})$, at a rate of $3^{\circ} \mathrm{C} / \mathrm{min}$ until reach $240{ }^{\circ} \mathrm{C}$ (for $10 \mathrm{~min}$ ); the detector temperature was $250{ }^{\circ} \mathrm{C}$. $1 \mu \mathrm{L}$ injection volume, previously the essential oil was diluted into $n$-hexane (1:10). The MS conditions were triple quadrupole type of ion 
detector operating by electronic impact (70 $\mathrm{eV}, 45$ to $450 \mathrm{Da}$ ). The identification and quantification of chemical constituents were obtained based on the areas of corresponding chromatographic peaks, determination of the Kovats Index, comparison with database records and the literature. Peaks with similarity of $95 \%$ or greater was considered identified. ${ }^{33-35}$

\subsection{Inclusion complexes preparation}

The inclusion complex of CZEO and $\beta-C D$ was prepared according to method proposed by Jantarat et al., ${ }^{28}$ with some modifications. The inclusion complexes of CZEO/ $\beta-C D$ were prepared at a molar ratio $1: 1$, defined according to CZEO composition (90\% estragole), using two preparation methods, co-precipitation coupled to freeze drying and spray drying.

For co-precipitation coupled to freeze drying, an adequate mass of CZEO was solubilized in ethanol PA, while the $\beta-C D$ was solubilized in water at $55^{\circ} \mathrm{C}$. The CZEO was added under stirring to $\beta-C D$ solution, removed from the heat, and stirred continuously for $4 \mathrm{~h}$ at $150 \mathrm{rpm}$ at an average temperature of $25^{\circ} \mathrm{C} \pm 1{ }^{\circ} \mathrm{C}$. After this period, the obtained suspension was left in a refrigerator $\left(4^{\circ} \mathrm{C}\right)$ overnight to accomplish the precipitation of inclusion complex. Then, the precipitate was collected, lyophilized at $-85^{\circ} \mathrm{C}$ in Freeze dryer (Liobras L101). The obtained inclusion complex is designed CZEO/ $\beta$-CD FD.

For spray drying, the suspension formed by the CZEO and $\beta-C D$ was homogenized, as described previously, followed by spray drying (BUCHI B-290), under the following conditions: input temperature $105{ }^{\circ} \mathrm{C}$, pressure 0.9 bar and sample of $3 \mathrm{~mL} \cdot \mathrm{min}^{-1}$. The obtained inclusion complex is designed CZEO/ $\beta$-CD SD.
The resulting inclusion complexes powder was kept in a desiccator at $25 \pm 1{ }^{\circ} \mathrm{C}$ and protected from light.

\subsection{Inclusion complexes characterization}

\subsubsection{Quantification of CZEO components}

For determination the concentration of the CZEO components present in the inclusion complexes, an analytical curve was prepared from several dilutions of estragole standard (Sigma-Aldrich) in $n$-hexane, obtaining seven dilutions ranging from 5 to $500 \mathrm{mg} \cdot \mathrm{L}^{-1}$. These solutions were analysed by GC-MS, as previously described. All the dilutions are prepared in triplicate.

\subsubsection{Complexation efficiency}

The total amount of oil in the inclusion complex was determined by method of extraction with solvent proposed by Rocha et al $^{19}$, with some modifications. Briefly, samples equivalent to $10 \mathrm{mg}$ of CZEO of inclusion complex were solubilized with $4.0 \mathrm{~mL}$ of distilled water in a test tube sealed with a Bakelite screw cap and extracted with $4.0 \mathrm{~mL}$ of $n$-hexane. For this, the mixture was heated in a water bath at a temperature of $85 \pm 2{ }^{\circ} \mathrm{C}$ for $15 \mathrm{~min}$ with intermittent shaking. Then it was cooled to room temperature. The $n$ hexane phase containing the essential oil was collected with a pipette, and the aqueous phase was further subjected to two successive extractions with $n$-hexane $(2 \times 4.0 \mathrm{~mL})$. The combined extracts were appropriately diluted and analysed by GC-MS for determination of complexation efficiency (CE) through equation 1. Measurements were done in triplicate.

Equation 1: $\quad C E=\frac{\text { Aic }}{\text { Aczeo }} \times 100$ 
Where $A_{I C}$ is the estragole peak area in the inclusion complex, and $A_{\text {czzo }}$ is the estragole peak area identified in the CZEO.

\subsubsection{ATR-FTIR spectroscopy}

The Attenuated Total Reflectance Fourier Transform Infrared spectroscopy spectrum (ATR-FTIR) of CZEO, $\beta-C D, C Z E O / \beta-C D$ FD and $C Z E O / \beta-C D$ SD inclusion complexes were obtained in the mid IR $\left(4000-600 \mathrm{~cm}^{-1}\right)$ using the spectrometer Agilent Carey 630. The samples of CZEO, $\beta-C D$ and inclusion complexes were placed directly on the surface of the crystal of the ATR accessory, with light pressure applied to promote contact between the solid samples and the crystal surface. The spectra were obtained with 64 scans and a resolution of $4 \mathrm{~cm}^{-1}$

\subsubsection{Raman spectroscopy}

The Raman spectra analysis was obtained with a Bruker Senterra dispersive Raman microscope with a charge-coupled device (CCD) detection system, with a $\times 50$ objective. The excitation wavelength was $785 \mathrm{~nm}$, obtained using a solid-state laser. The measurements were calibrated with crystalline silicon and the resolution was about $3 \mathrm{~cm}^{-1}$ and for each spectrum 10 accumulations of $10 \mathrm{~s}$ for each spectrum.

\section{Results and Discussion}

\subsection{Chemical composition of CZEO}

C. zehntneri essential oil (CZEO) was obtained from the leaves hydrodistillation, the yield of EO extraction was $3 \%$. Several studies have shown that the $C$. zehntneri leaves have a rich essential oil content that usually comprises $2-4 \%$ of the weight of dry leaves. The variance can be associated to the hour of leaf collection, season of the year, locality, climate, soil type, among others. ${ }^{9}$

The essential oil components identification was accomplished by comparison of their GCMS retention indices, being possible to identify $98.1 \%$ of integrated constituents. Mass spectra were considered coincident if the similarity index was higher than $95 \%$. Figure 2 shows the chromatogram of CZEO, the composition of CZEO was $90.1 \%$ estragole (i), the main component, $4.9 \%$ bicyclogermacrene (ii), $2.1 \%$ Methyl Eugenol (iii), $1.0 \% \beta$-caryophyllene (iv) and $1.9 \%$ compounds could not be identified.

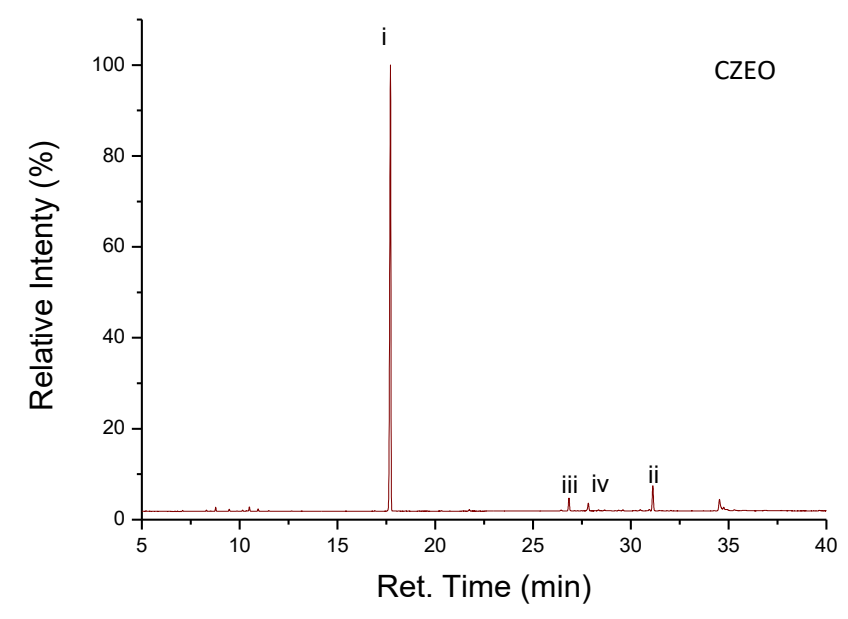

Figure 2. Chromatogram of $C$. zehntneri essential oil 
According to Andrade et al., ${ }^{36}$ the main component of the essential oil of $C$. zenhtneri from Simões-PI, Brazil, is estragole. Estragole is a component of EO with low solubility in water and high volatility. Nevertheless, the limited characteristics of the estragole can be overcome by the inclusion complex formation with cyclodextrins. ${ }^{37}$

\subsection{Inclusion complexes preparation}

Inclusion complex is an alternative process to increase the stability of volatile compounds, protecting them from adverse environmental conditions, and this is defined as a process whereby particles are surrounded by a coating, producing small capsules with many useful properties. ${ }^{38}$ Several methods have been reported for the preparation of solid inclusion complexes with CDs. For this study, solid inclusion complexes were prepared using co-precipitation coupled to freeze drying and spray drying methods.

The determination of the practical yield is an important measure to know the efficiency of any process and to select the most effective method to produce inclusion complexes. ${ }^{30}$ Thus, the practical yield of the complexes was calculated as a function of the mass obtained from the complex formation and the sum of the respective initial masses.

The practical yields obtained for CZEO/ $\beta$ CD FD and CZEO/ $\beta-C D$ SD are $79 \%$ and $82 \%$, respectively, values considered high for these techniques. Rudrangi et al, ${ }^{30}$ in their study of inclusion complex preparation methods, reported a percentage practical yield of 90.1 $\%$ freeze drying and $60.3 \%$ spray drying. Instead, Wang et al, ${ }^{39}$ reported yields of 78.2 $\%$ related to an oil complexed by coprecipitation method. All inclusion methods result in the loss of mass of the complexes. A higher yield was expected, but recovery of the $C Z E O / \beta-C D$ SD was difficult due to electrostatic deposition of the complex on the internal chamber wall. Instead, the CZEO/ $\beta$ $C D$ FD yield must be related to an amount of complex that can be dissolved in the supernatant. Therefore, the preparation methods and the starting material directly influence the yield of the complexes.

Spray drying is the most commonly used encapsulation method in the food industry since it is cost effective, fast, large scale production and highly flexible. ${ }^{40}$ However, spray drying has some limitations related to use for heat sensitive materials and it requires precise adjustment of hot gas temperature used. ${ }^{41}$ On the other hand, freeze-drying is especially useful for heat labile guests, the low temperature minimises the loss of extremely volatile guests. The main disadvantage of this method resides without increasing scale and prolonged method. ${ }^{42}$

In this context, spray and freeze-drying operations gain importance. However, these are the processes which operate at different conditions of temperature and time, and hence results in products with different characteristics. These processes are widely used for the microencapsulation of extracts and other bioactive compounds from natural sources.

\subsection{Inclusion complexes characterization}

To extend the applications of EO, it is necessary to lower the volatility of the compounds to obtain a longer shelf life of products. The encapsulation processes are means by which a liquid EO is bounded in a transporter matrix to provide a dry powder. Controlling the volatility, one can also imagine a possibility to better test the EO biological effects. ${ }^{43}$

Complex formation is a dimensional fit between host cavity and guest molecule, which is mediated by non-polar attraction of lipophilic molecule to CD interior cavity lined with carbons, while their hydroxyl groups are oriented to their exterior surface hydrophilic. No covalent bonds are broken or formed during formation of the inclusion complex. ${ }^{27,42}$

The chromatograms of the constituents extracted from the inclusion complexes allowed to determine the presence of the estragole in the two preparation methods, 
demonstrating that the use of the spray drying technique, even using heating, was able to complex the ES (Figure 3).
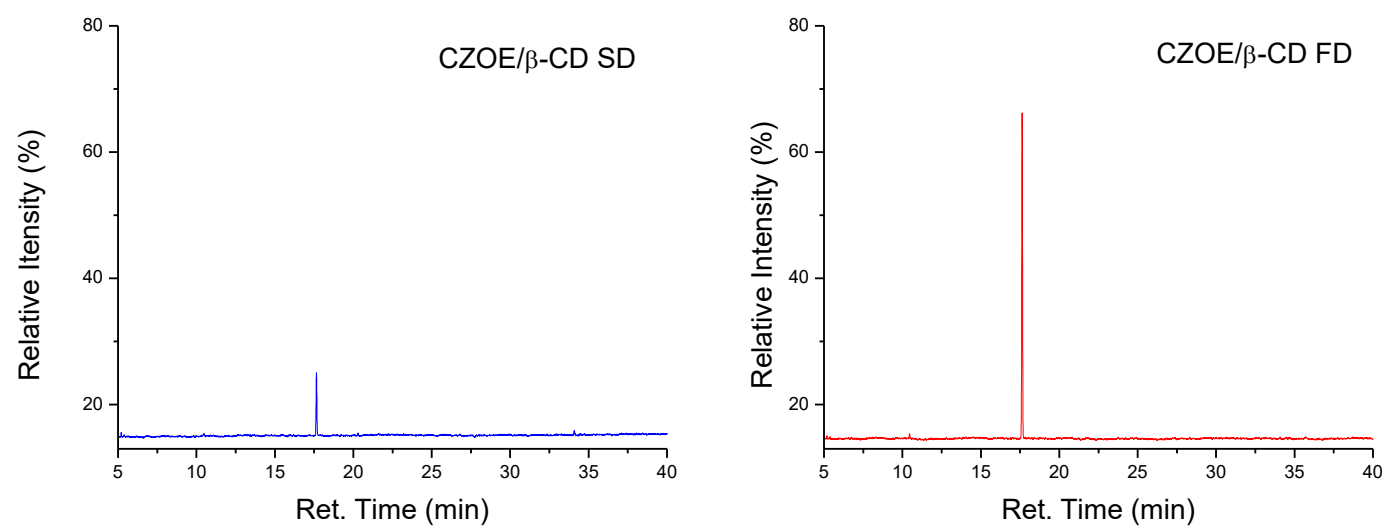

Figure 3. Chromatogram of $C$. zehntneri essential oil extracted from the inclusion complexes

The analytical curve was constructed with seven different concentrations $(5,10,50,100$, 200, 300, 400 and $500 \mathrm{mg} \mathrm{L}^{-1}$ ), with each concentration being prepared in triplicate. Through the equation, $y=11555 x-50619 ; R^{2}$ $=0.9964$, it was possible to quantify the mass of estragole present in the inclusion complexes, thus, in $100 \mathrm{mg}$ of CZEO/ $\beta-C D$ SD and $C Z E O / \beta-C D$ FD inclusion complexes have $1.2 \mathrm{mg}$ and $5.7 \mathrm{mg}$, respectively.

The efficiency of complexation, determined for the inclusion complexes prepared by co-precipitation coupled to freeze drying and spray drying, was determined in $50 \%$ and $10 \%$, respectively, demonstrating a higher complexation efficiency of estragole when prepared by coprecipitation coupled to freeze drying. Our results showed relatively high complexation efficiency using co-precipitation coupled to freeze drying as compared with Kfoury et al, ${ }^{44}$ study that used the same preparation method and $\beta-C D$ :ES ( $\beta-C D$ : estragole) molar ratio. The complexation efficiency differs due to the use of high temperatures in the spray drying, which may have caused the loss of the content of CZEO by volatilization. On the other hand, freeze drying uses high vacuum and low temperatures, reducing the loss by volatilization.
The formation of inclusion complex is favoured by the structure and physicochemical properties of the guest molecules, which must fit totally or partially in the $C D$ cavity. The molecular mass of the estragole (148 Da) is compatible with the size of $\beta-C D$ that is capable of complexing substance in the molecular mass range of 100 to $400 \mathrm{Da}{ }^{8,29}$

The extraction of the inclusion complex enabled to determine that only the estragole, the major constituent of CZEO was encapsulated. Thus, for the analyses of ATRFTIR and Raman, ES will be considered the only constituent of CZEO.

\subsection{ATR-FTIR spectroscopy}

ATR-FTIR spectroscopy can provide important advantages with respect to the classic FTIR technique, as a consequence of the fact that no sample preparation is required and spectra are obtained avoiding all the problems related to the usual dispersion of the sample in $\mathrm{KBr}$, allowing for faster measurements and higher reproducibility of the spectra, making ATR-FTIR technique very suitable also in showing differences in solid- 
state forms, including hydrated and polymorphic forms, and in the identification and characterization of pharmaceutical formulations. ${ }^{44,47}$
ATR-FTIR technique can be used to investigate the variation of shape, intensity and position of peaks. ${ }^{45}$ The ATR-FTIR of $\beta-C D$, CZEO, CZEO/ $\beta-C D$ SD and CZEO/ $\beta-C D$ FD inclusion complexes are shown in Figure 4.
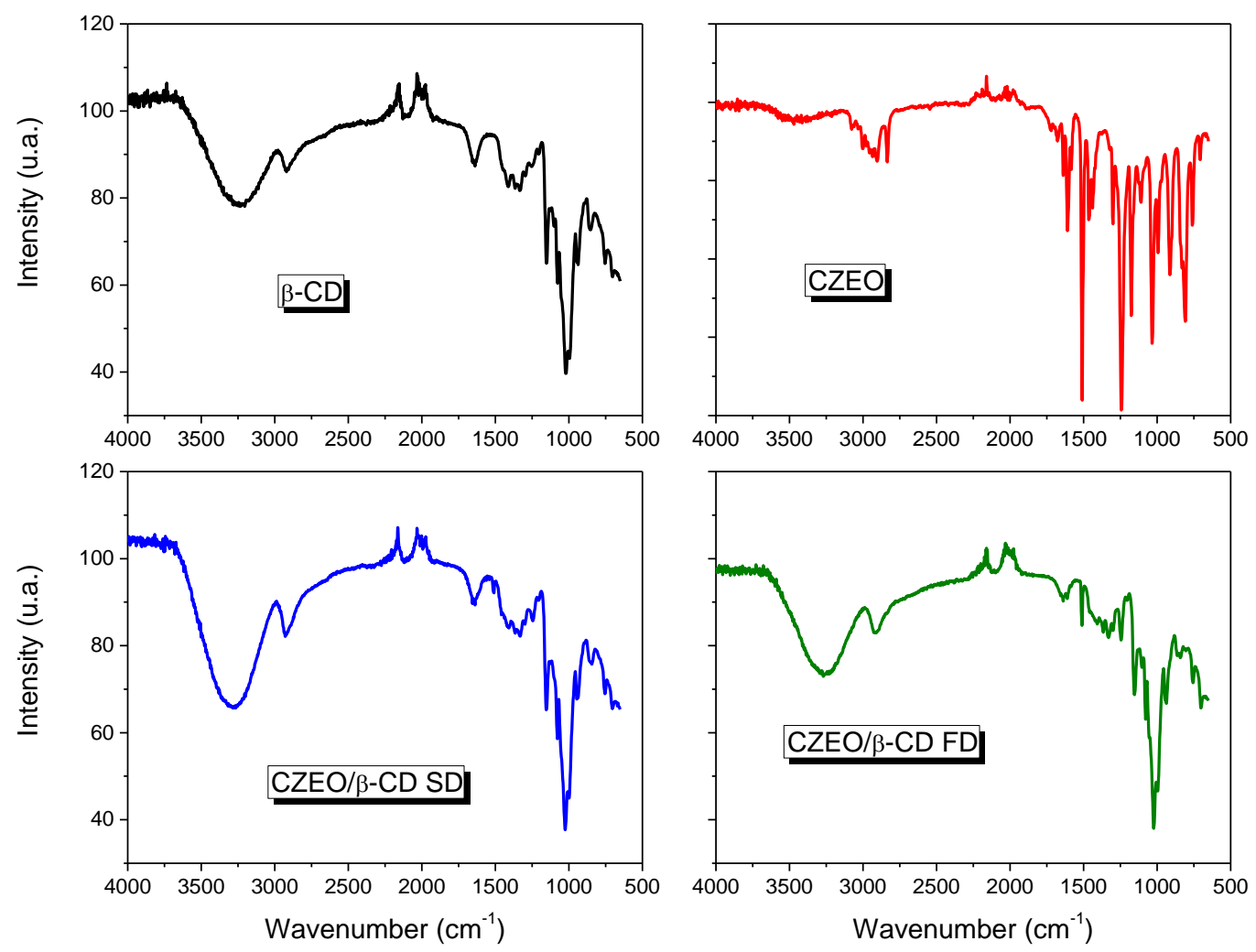

Figure 4. FTIR-ATR spectra of $\beta-C D, C Z E O, C Z E O / \beta-C D$ SD and CZEO/ $\beta-C D$ FD

The CZEO ATR-FTIR presents bands between 3077 and $2835 \mathrm{~cm}^{-1}$ (C-H stretching), 1645 and $1609 \mathrm{~cm}^{-1}$ (C=C stretching), $1513 \mathrm{~cm}^{-}$ ${ }^{1}$ (aromatic ring stretching), $1242 \mathrm{~cm}^{-1}$ (C-O aryl stretch). The $\beta-C D$ ATR-FTIR presents bands at $3231 \mathrm{~cm}^{-1}$ (O-H stretch), $2919 \mathrm{~cm}^{-1}$ (C$\mathrm{H}$ stretch), $1157 \mathrm{~cm}^{-1}$ (C-O stretch) and 1020 $\mathrm{cm}^{-1}$ (C-O-C stretch). The CZEO/ $\beta-C D$ SD ATRFTIR did not show significant alterations when compared to ATR-FTIR bands of free $\beta-C D$ indicating that no strong interaction existed among estragole and $\mathrm{C}-\mathrm{C}, \mathrm{C}-\mathrm{O}-\mathrm{C}$ or $\mathrm{OH}$ groups of $\beta-C D$, confirmed by the low complexing efficiency of the spray drying preparation method.

The CZEO/ $\beta$-CD FD ATR-FTIR spectra were similar to the $\beta$-CD ATR-FTIR, but some peaks of CZEO (at 1245 and $1518 \mathrm{~cm}^{-1}$ attributed, respectively, to C-O aryl stretch and aromatic ring stretching) were still detected. However, they represented a very low strength probably due the low estragole quantity $(5.7 \% \mathrm{w} / \mathrm{w})$ in the inclusion complexes as compared to the massive host. In addition to these effects, the $\mathrm{OH}$ stretching bands of $\beta-\mathrm{CD}$ were displaced at $3231 \mathrm{~cm}^{-1}$ to $3280 \mathrm{~cm}^{-1}$ in CZEO/ $\beta-C D$ SD and $3253 \mathrm{~cm}^{-1}$ in CZEO/B-CD FD, and the $C-H$ stretch band of $\beta-C D$ at $2919 \mathrm{~cm}^{-1}$ to $2926 \mathrm{~cm}^{-}$ ${ }^{1}$ in CZEO/ $\beta-C D$ SD and $2906 \mathrm{~cm}^{-1}$ in CZEO/ $\beta$ CD FD. ${ }^{8,19}$ The results of this study corroborate with those obtained by Kfoury et $\mathrm{al}^{45}$ and Aguiar et al. ${ }^{8}$

Therefore, the ATR-FTIR technique enabled good evidence to be obtained for complex formation between $\beta-C D$ and CZEO using the co-precipitation coupled to freeze 
drying method. The interactions appeared to occur due to the entry of ES aromatic ring into the $C D$ cavity.

\subsection{Raman spectroscopy}

Raman spectroscopy has been widely applied in the pharmaceutical industry and has been suggested as a potential tool for the study of the formation of inclusion complexes. In comparison to FTIR spectroscopy, Raman has some major advantages, coming from the fact that the Raman effect manifests itself in the light scattered a sample as opposed to the
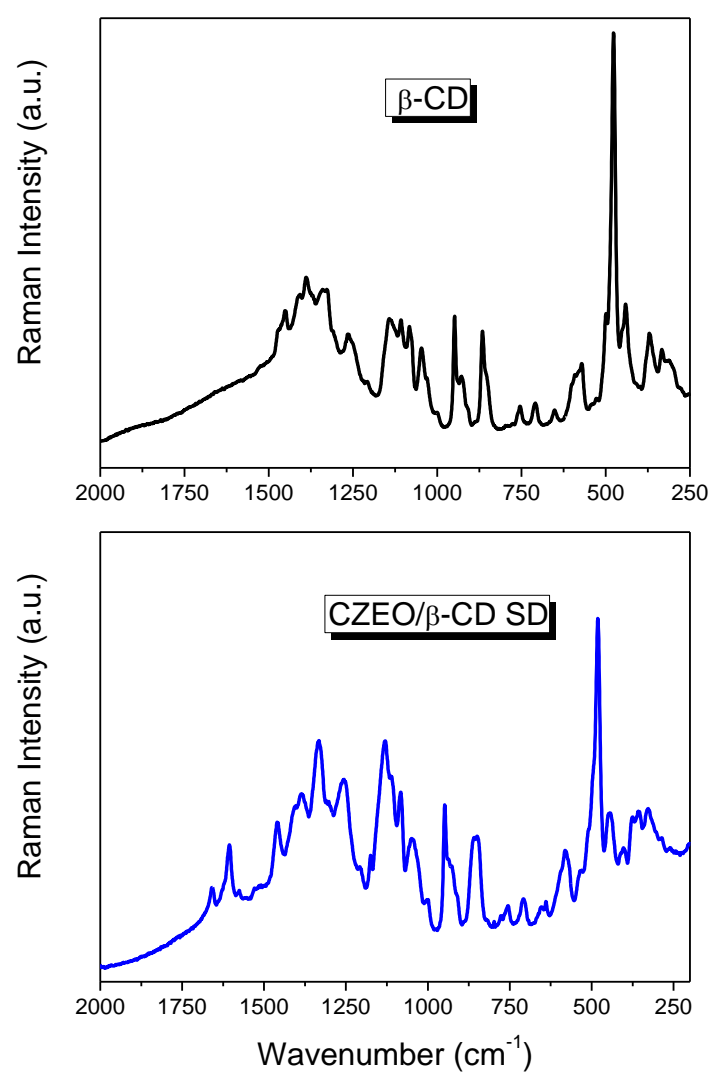

light absorbed by a sample. Consequently, Raman spectroscopy needs little or no sample preparation. ${ }^{46,48,49}$

The principle of Raman spectroscopy is the changing polarizability of a bond through the absorption of light. Consequently, structures with unsaturated carbon bonds, especially when conjugated, are highly Raman active. Raman can be used monitoring of the vibration of $\mathrm{C}=\mathrm{C}$ bands, which are highly sensitive to the formation of the inclusion complex. ${ }^{19,47,48}$ The Raman spectra da $\beta-C D$, CZEO, CZEO/ $\beta-C D$ SD and CZEO/ $\beta-C D$ FD inclusion complexes are shown in Figure 5.
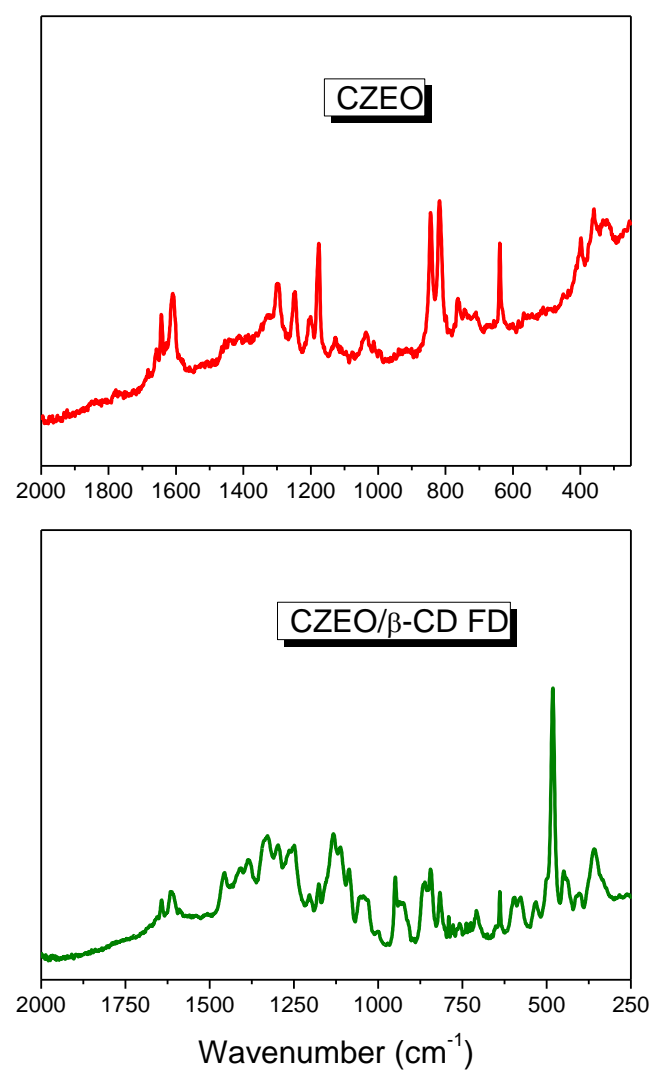

Figure 5. Raman spectra of $\beta-C D, C Z E O, C Z E O / \beta-C D$ SD and CZEO/ $\beta-C D$ FD 
In the Raman spectrum of CZEO, Figure 5, presents bands around $1643 \mathrm{~cm}^{-1} \quad(\mathrm{C}=\mathrm{C}$ stretch), related to a double bond nonconjugated of estragole, $1610 \mathrm{~cm}^{-1} \quad(C=C$ aromatic ring), 1298 and $1176 \mathrm{~cm}^{-1}$ (C-O-C stretch), 845 and $818 \mathrm{~cm}^{-1}$ (C-H aromatic ring) and $638 \mathrm{~cm}^{-1}$ ( $p$-aromatic ring). These peaks represent the fingerprint of the CZEO. Analysing the $\beta-C D$ spectra, the bands around $1339,948,861,570$, and $479 \mathrm{~cm}^{-1}$ can be related to $\mathrm{C}-\mathrm{H}$ stretch, alcohol hydroxyls, C-O$\mathrm{C}$ bonds between glucoses, among other correlations. When comparing the Raman spectra of CZEO/ $\beta-C D$ FD with CZEO, some bands have practically the same wavenumber, but increased intensity, such as, the bands around $1643 \mathrm{~cm}^{-1}$ (C=C stretch), $1616 \mathrm{~cm}^{-1}$ ( $\mathrm{C}=\mathrm{C}$ aromatic ring), 1298 and $1176 \mathrm{~cm}^{-1}$ (C-OC stretch), 847 and $820 \mathrm{~cm}^{-1}$ (C-H aromatic ring) and $638 \mathrm{~cm}^{-1}$ ( $p$-aromatic ring). ${ }^{46-50}$ When analysing Raman spectra of CZEO/ $\beta-C D$ SD complex, same characteristics are presents, but some bands were not observed, and the spectrum has greater similarity with the $\beta-C D$ spectrum.

From the Raman spectra is possible to observe the formation of inclusion complex between $\beta-C D$ and CZEO and was not observed the appearance of new vibrational bands in the Raman spectra of the inclusion complexes, indicating that non-covalent chemical bonds were formed between the CZEO and $\beta-C D$.

\section{Conclusion}

The $C$. zehntneri leaves have a rich essential oil content, which was analysed by CG-MS and presented estragole as majority component. The CZEO and $\beta-C D$ inclusion complexes were prepared by co-precipitation coupled to freeze drying and spray drying methods and characterized by ATR-FTIR and Raman. The efficiency of complexation (EC\%) was determined for each inclusion complex and demonstrates the higher EC\% for solid inclusion complexes prepared using coprecipitation coupled to freeze drying method, as compared to spray drying method. ATR-FTIR and Raman spectroscopy confirms the evidence the formation of the inclusion complex between CZEO and $\beta-C D$ by both preparation methods. Thus, this study clearly demonstrates the encapsulation of ES with $\beta$ $C D$, suggesting that the complexation with $C D$ could be an effective way to improve the stability of EO.

\section{Acknowledgments}

The authors thanks to the UFPI, Conselho Nacional de Desenvolvimento Científico $e$ Tecnológico - CNPq - Coordenação de Aperfeiçoamento de Pessoal de Nível Superior - CAPES- for the master's degree and the scientific initiation scholarships granted.

\section{References}

${ }^{1}$ Mendel, M.; Chłopecka, M.; Dziekan, N.; Karlik, W. Phytogenic feed additives as potential gut contractility modifiers - A review. Animal Feed Science and Technology 2017, 230, 30. [CrossRef].

2 Bagamboula, C. F.; Uyttendaele, M.; Debevere, J. Inhibitory effect of thyme and basil essential oils, carvacrol, thymol, estragol, linalool and $p$-cymene towards Shigella sonnei and S. flexneri. Food Microbiology 2004, 21, 33. [CrossRef]

${ }^{3}$ Berry, P. E.; Hipp, A. L.; Wurdack, K. J.; Van Ee, B.; Riina, R. Molecular phylogenetics of the giant genus Croton and tribe Crotoneae (Euphorbiaceae sensu stricto) using ITS and trnL-trnF DNA sequence data. American Journal of Botany 2005, 92, 1520. [CrossRef] [PubMed]

${ }^{4}$ Sodré, R. C.; da Silva, M. J. O gênero Croton L. (Euphorbiaceae - Crotonoideae) na Floresta Nacional de Silvania, Goias, Brasil. Iheringia. Série Botânica 2015, 89, 70. [Link]

${ }^{5}$ da Costa, J. G. M.; Rodrigues, F. F. G.; Angélico, E. C.; Pereira, C. K. B.; De Souza, E. O.; Caldas, G. F. R.; Silva, M. R.; Santos, N. K. A.; Mota, M. L.; Dos Santos, P. F. Composição 
química e avaliação da atividade antibacteriana e toxicidade do óleo essencial de Croton zehntneri (variedade estragol). Revista Brasileira de Farmacognosia 2008, 18, 583. [CrossRef].

${ }^{6}$ De Morais, S. M.; Catunda, F. E. A.; Da Silva, A. R. A.; Neto, J. S. M.; Rondina, D.; Leal Cardoso, J. H. Atividade antioxidante de óleos essenciais de espécies de Croton do Nordeste do Brasil. Química Nova 2006, 29, 907. [CrossRef].

${ }^{7}$ Silva-Alves, K. S.; Ferreira-Da-Silva, F. W.; Coelho-De-Souza, A. N.; Albuquerque, A. A. C.; Do Vale, O. C.; Leal-Cardoso, J. H. Essential oil of Croton zehntneri and its main constituent anethole block excitability of rat peripheral nerve. Planta Medica 2015, 81, 292. [CrossRef] [PubMed].

${ }^{8}$ Aguiar, U. N.; De Lima, S. G.; Rocha, M. S.; De Freitas, R. M.; Oliveira, T. M.; Silva, R. M.; Moura, L. C. B.; Almeida, L. T. G. Preparação e caracterização do complexo de inclusão do óleo essencial de Croton zehntneri com $\beta$ ciclodextrina. Química Nova 2014, 37, 50. [CrossRef].

${ }^{9}$ Cavalcanti, J. M.; Leal-Cardoso, J. H.; Diniz, L. R. L.; Portella, V. G.; Costa, C. O.; Linard, C. F. B. M.; Alves, K.; Rocha, M. V. A. de P.; Lima, C. C; Cecatto, V. M.; Coelho-De-Souza, A. N. The essential oil of Croton zehntneri and transanethole improves cutaneous wound healing. Journal of Ethnopharmacology 2012, 144, 240. [CrossRef] [PubMed].

10 Zeller, A.; Horst, K.; Rychlik, M. Study of the metabolism of estragole in humans consuming fennel tea. Chemical Research in Toxicology 2009, 22, 1929. [CrossRef] [PubMed].

${ }^{11}$ Lewinsohn, E.; Ziv-raz, I.; Dudai, N.; Tadmor, Y.; Lastochkin, E.; Larkov, O.; Chaimovitsh, D.; Ravid, U.; Putievsky, E.; Pichersky, E.; Shoham, Y. Biosynthesis of estragole and methyleugenol in sweet basil (Ocimum basilicum L). Developmental and chemotypic association of allylphenol O-methyltransferase activities. Plant Science 2000, 160, 27. [CrossRef]

${ }^{12}$ Chang, C. L.; Cho, I. K.; Li, Q. X. Insecticidal activity of basil oil, trans-anethole, estragole, and linalool to adult fruit flies of Ceratitis capitata, Bactrocera dorsalis, and Bactrocera cucurbitae. Journal of Economic Entomology 2009, 102, 203. [CrossRef] [PubMed].

13 Diao, W.-R.; Zhang, L.-L.; Feng, S.-S.; Xu, J.G. Chemical Composition, Antibacterial Activity, and Mechanism of Action of the Essential Oil from Amomum kravanh. Journal of Food Protection 2014, 77, 1740. [CrossRef] [PubMed].

${ }^{14}$ Ponte, E. L.; Sousa, P. L.; Rocha, M. V. A. P.; Soares, P. M. G.; Coelho-de-Souza, A. N.; LealCardoso, J. H.; Assreuy, A. M. S. Comparative study of the anti-edematogenic effects of anethole and estragole. Pharmacological Reports 2012, 64, 984. [CrossRef] [PubMed].

${ }^{15}$ Rodrigues, L. B.; Martins, A. O. B. P.; Cesário, F. R. A. S.; Castro, F. C.; De Albuquerque, T. R.; Fernandes, M. N. M.; Da Silva, B. A. F; Júnior, L. J. Q.; da Costa, J. G. M.; Coutinho, H. D. M.; Barbosa, R.; Menezes, I. R. A. Antiinflammatory and antiedematogenic activity of the Ocimum basilicum essential oil and its main compound estragole: In vivo mouse models. Chemico-Biological Interactions 2016, 257, 14. [CrossRef] [PubMed].

${ }^{16}$ Cabral, P. H. B.; Campos, R. M.; Fonteneles, M. C.; Santos, C. F.; Leal Cardoso, J. H.; Nascimento, N. R. F. Do Effects of the essential oil of Croton zehntneri and its major components, anethole and estragole, on the rat corpora cavernosa. Life Sciences 2014, 112, 74. [CrossRef] [PubMed].

17 Obolskiy, D.; Pischel, I.; Feistel, B.; Glotov, N.; Heinrich, M. Artemisia dracunculus L. (tarragon): A critical review of its traditional use, chemical composition, pharmacology, and safety. Journal of Agriculture and Food Chemistry 2011, 59, 11367 [CrossRef] [PubMed].

${ }^{18}$ Kfoury, M.; Landy, D.; Auezova, L.; GreigeGerges, H.; Fourmentin, S. Effect of cyclodextrin complexation on phenylpropanoids' solubility and antioxidant activity. Beilstein Jounal of Organic Chemistry 2014, 10, 2322. [CrossRef] [PubMed].

${ }^{19}$ Rocha, M. S. Characterization of the inclusion complex of the essential oil of Lantana camara $L$. and $\beta$-cyclodextrin by vibrational spectroscopy, GC-MS, and X-ray 
diffraction. Journal of Inclusion Phenomena and Macrocyclic Chemistry 2018, 91, 95. [CrossRef].

${ }^{20}$ Kfoury, M.; Auezova, L.; Greige-Gerges, H.; Larsen, K. L.; Fourmentin, S. Release studies of trans-anethole from $\beta$-cyclodextrin solid inclusion complexes by Multiple Headspace Extraction. Carbohydrate Polymers 2016, 151, 1245. [CrossRef].

${ }^{21}$ Rakmai, J.; Cheirsilp, B.; Mejuto, J. C.; Torrado-Agrasar, A.; Simal-Gándara, J. Physico-chemical characterization and evaluation of bio-efficacies of black pepper essential oil encapsulated in hydroxypropylbeta-cyclodextrin. Food Hydrocolloids 2017, 65, 157. [CrossRef].

${ }^{22}$ Kfoury, M.; Auezova, L.; Greige-Gerges, H.; Fourmentin, S. Promising applications of cyclodextrins in food: Improvement of essential oils retention, controlled release and antiradical activity. Carbohydrate Polymers 2015, 131, 264. [CrossRef] [PubMed].

${ }^{23}$ Abarca, R. L.; Rodríguez, F. J.; Guarda, A.; Galotto, M. J.; Bruna, J. E. Characterization of beta-cyclodextrin inclusion complexes containing an essential oil component. Food Chemistry 2015, 196, 968. [CrossRef] [PubMed].

${ }^{24}$ Li, W.; Liu, X.; Yang, Q.; Zhang, N.; Du, Y.; Zhu, H. Preparation and characterization of inclusion complex of benzyl isothiocyanate extracted from papaya seed with $\beta$ cyclodextrin. Food Chemistry 2015, 184, 99. [CrossRef] [PubMed].

${ }^{25}$ Zhu, X.-L.; Wang, H.-B.; Chen, Q.; Yang, W.C.; Yang, G.-F. Preparation and characterization of inclusion complex of iprodione and beta-cyclodextrin to improve fungicidal activity. Journal of Agricultural and Food Chemistry 2007, 55, 3535. [CrossRef] [PubMed].

${ }^{26}$ de Souza, A. R.; Morgon, H. Interação entre o Dímero de Apocinina e Ciclodextrina. Revista Virtual de Química 2016, 8, 417. [CrossRef].

${ }^{27}$ Adeoye, O.; Costa, C.; Casimiro, T.; Aguiarricardo, A.; Cabral-marques, H. Preparation of ibuprofen/hydroxypropyl- $\psi$-cyclodextrin inclusion complexes using supercritical $\mathrm{CO}_{2}-$ assisted spray drying. Journal of Supercritical Fluids 2018, 133, 479. [CrossRef]
28 Jantarat, C.; Sirathanarun, P.; Ratapongsai, S.; Watcharaka, P.; Sunyapong, S.; Wadu, A. Curcumin-Hydroxypropyl- $\beta$-Cyclodextrin Inclusion Preparation Methods Effect of Common Solvent Evaporation, Freeze Drying, dan $\mathrm{pH}$ Shift on Solubility and Stability of Curcumin. Tropical Journal of Pharmaceutical Research 2004, 13, 1215 [CrossRef].

${ }^{29}$ Cunha-Filho, M. S. S.; Sá-Barreto, L. C. L. Utilização de ciclodextrinas na formação de complexos de inclusão de interesse farmacêutico. Journal of Basic and Applied Pharmaceutical Sciences 2007, 28, 1. [Link].

${ }^{30}$ Rudrangi, S. R. S.; Bhomia, R.; Trivedi, V.; Vine, G. J.; Mitchell, J. C.; Alexander, B. D.; Wicks, S. R. Influence of the preparation method on the physicochemical properties of indomethacin and methyl- $\beta$-cyclodextrin complexes. International Journal of Pharmaceutics 2015, 479, 381. [CrossRef] [PubMed].

${ }^{31}$ Andrade, T. A.; Freitas, T. S.; Araújo, F. O.; Menezes, P. P.; Dória, G. A. A.; Rabelo, A. S.; Quintans-Júnior, L. J.; Santos, M. R. V.; Bezerra, D. P.; Serafini, M. R.; Menezes, I. R. A.; Nunes, P. S.; Araújo, A. A. S.; Costa, M. S.; Campina, F. F.; Santos, A. T. L.; Silva, A. R. P.; Coutinho, H. D. M. Physico-chemical characterization and antibacterial activity of inclusion complexes of Hyptis martiusii Benth essential oil in $\beta$-cyclodextrin. Biomedicine \& Pharmacotherapy 2017, 89, 201. [CrossRef] [PubMed].

${ }^{32}$ Ho, S.; Yin, Y.; James, D.; Fong, L. Inclusion complexation of catechin by $\beta$-cyclodextrins: Characterization and storage stability. LWT Food Science and Technology 2017, 86, 555. [CrossRef].

${ }^{33}$ Van Den Dool, H.; Dec. Kratz, P. A generalization of the retention index system including linear temperature programmed gas-liquid partition chromatography. Journal of Chromatography A. A 1963, 11, 463. [CrossRef] [PubMed].

${ }^{34}$ Adams, R.; Identification of Essential oil components by gas Chromatography/Quadrupole Mass Spectroscopy Allured Publishing Corporation: Carol Stream, 2007.

${ }^{35}$ Lima, S. G. DE.; Neto, J. M. M.; Cito, A. M. G. 
L.; Costa, J. G. M. D. A.; Reis, F. A. M. Monoterpenes, sesquiterpenes and fatty acids from Julocroton triqueter (Euphorbiaceae) from Ceará - Brazil. Journal of the Chilean Chemical Society 2009, 1, 55. [CrossRef]

${ }^{36}$ Andrade, T. C. B.; Lima, S. G. D.; Freitas, R. M.; Rocha, M. S.; Islam, T.; Silva, T. G. D.; Militão, G. C. G. Isolation, characterization and evaluation of antimicrobial and cytotoxic activity of estragole, obtained from the essential oil of Croton zehntneri (Euphorbiaceae). Anais da Academia Brasileira de Ciências 2015, 87, 173. [CrossRef] [PubMed].

37 Godfrey, P. D.; McNaughton, D.; Evans, C. J. The millimetre-wave spectrum of estragole. Chemical Physics Letters 2013, 580, 37. [CrossRef].

${ }^{38}$ Rezende, Y. R. R. S.; Nogueira, J. P.; Narain, $\mathrm{N}$. Microencapsulation of extracts of bioactive compounds obtained from acerola (Malpighia emarginata $\mathrm{DC}$ ) pulp and residue by spray and freeze drying: Chemical, morphological and chemometric characterization. Food Chemistry 2018, 254, 281. [CrossRef].

${ }^{39}$ Wang, J.; Cao, Y.; Sun, B.; Wang, C. Physicochemical and release characterisation of garlic oil- $\beta$ - cyclodextrin inclusion complexes. Food Chemistry 2011, 127, 1680. [CrossRef].

40 Moayyedi, M.; Eskandari, M. H.; Rad, A. H. E.; Ziaee, E.; Khodaparast, M. H. H.; Golmakani, M. T. Effect of drying methods (electrospraying, freeze drying and spray drying) on survival and viability of microencapsulated Lactobacillus rhamnosus ATCC 7469. Journal of Functional Foods 2018, 40, 391. [CrossRef].

${ }^{41}$ Ali, M. E.; Lamprecht, A. Spray freeze drying for dry powder inhalation of nanoparticles. European Journal of Pharmaceutics and Biopharmaceutics 2014, 87, 510. [CrossRef] [PubMed].
42 Del Valle, E. M. M. Cyclodextrins and their uses: A review. Process Biochemistry 2004, 39, 1033. [CrossRef]

${ }^{43}$ Başer, K.; Buchbauer, G.; Handbook of Essential oils: Science, Technology, and Applications 1a. ed, Taylor and Francis Group: New York, 2010, cap 10. [CrossRef]

${ }^{44}$ Kazarian, S. G.; Wray, P. S.; Applications of FTIR Spectroscopic Imaging in Pharmaceutical Science. Raman, Infrared, and Near-Infrared Chemical Imaging, Wiley: Nova Jersey 2010. [CrossRef]

${ }^{45}$ Kfoury, M.; Auezova, L.; Ruellan, S.; GreigeGerges, H.; Fourmentin, S. Complexation of estragole as pure compound and as main component of basil and tarragon essential oils with cyclodextrins. Carbohydrate Polymers 2015, 118, 156. [CrossRef] [PubMed].

${ }^{46}$ Oliveira, V. E.; Almeida, E. W. C.; Castro, H. V.; Edwards, H. G. M.; Dos Santos, H. F.; de Oliveira, L. F. C. Carotenoids and $\beta$ Cyclodextrin Inclusion Complexes: Raman Spectroscopy and Theoretical Investigation. The Journal of Physical Chemistry A 2011, 115, 8511. [CrossRef] [PubMed].

${ }^{47}$ Gudi, G.; Krähmer, A.; Krüger, H.; Hennig, L.; Schulz, H. Discrimination of fennel chemotypes applying $I R$ and Raman spectroscopy: Discovery of a new $\mathrm{p}$-asarone chemotype. Journal of Agricultural and Food Chemistry 2014, 62, 3537. [CrossRef] [PubMed].

${ }^{48}$ Larkin, P. Infrared and Raman spectroscopy: principles and spectral interpretation. 1a. ed, Elsevier: Amsterdam, 2011. [Link]

${ }^{49}$ Schulz, H.; Baranska, M. Identification and quantification of valuable plant substances by IR and Raman spectroscopy. Vibrational Spectroscopy 2007, 43, 13. [CrossRef].

50 Schulz, H.; Özkan, G.; Baranska, M.; Krüger, H.; Özcan, M. Characterisation of essential oil plants from Turkey by IR and Raman spectroscopy. Vibrational Spectroscopy 2005, 39, 249. [CrossRef]. 